\title{
Buckwheat or maize? Ultimately, potatoes! The Slovenian experience with maize in the nineteenth and twentieth centuries
}

\author{
Žarko Lazarević \\ Institute of Contemporary History \\ University of Primorska, Faculty of Humanities
}

\section{Introduction}

In the nineteenth century, modernization or the introduction of the achievements of the agrarian technical revolution took place in Slovenian agriculture, as Jože Maček put it (Maček 1995). This process changed the technological aspects of agriculture, and new crops were being introduced. One of them - maize - had a far-reaching impact: it became the driving force of the changing structure of crops. We can hardly say that maize has been overlooked by historiography. Its rise has been simply impossible to ignore, as it influenced the structure of agriculture and people's diet. However, it never achieved the cult status of potatoes, which became known as the plant and crop that put an end to hunger and malnutrition. Much research has been dedicated to potatoes. The cult status of potatoes in Slovenia was established by the book with a very suggestive title Kruh ubogih ("The Poor Man's Bread", Stabej 1977). This work corroborated the thesis that only potatoes managed to ensure adequate nutrition of the population. Allegedly, they also contributed to population growth. Another emphasis of the book was social - we could even say class-related. The stratification of society was supposedly related to potatoes, which delivered the lower social strata from famine and food shortage. This thesis left no room for the importance of maize as a supplementary crop. With the exception of the western part of Slovenia, maize could not compete with potatoes as far as the nutrition of the population was concerned. In the majority of the territory, it was 
usually a supplementary foodstuff, but its value would occasionally spike, especially when the potato harvest was poor due to potato blight or unfavourable weather conditions. In such difficult times, people would resort to maize. We can thus state that both maize and potatoes contributed to the long-term stability of the food supply. The finding that potatoes and maize initially mostly established themselves in the poorer parts is indisputable (Makarovič 1991).

By the middle of the nineteenth century, maize had been successfully introduced: by that time, it had already become well known and present throughout the Slovenian territory. It arrived in this territory from two directions: the Padan Plain and the Pannonian Croatia. The stages of pre-adaptation and adaptation concluded in the eighteenth century. During the pre-adaptation stage, people familiarized themselves with the advantages and potentials of maize and introduced it to the fields. In the adaptation stage, maize production was already established: it was used as livestock feed and in the daily diet of the population. At the beginning of the nineteenth century, there was still much room for the expansion of this crop. The process was rather slow, the conditions varied from province to province, and the central Slovenian territory lagged behind the other parts for a long time. However, maize kept becoming more popular with time, and in the last decades of the nineteenth century, its establishment was indisputable. Its economic significance kept increasing, and by the onset of World War II, it had become the most important crop in Slovenia besides wheat and potatoes.

Similarly as in other countries, the fundamental advantage of maize was its productivity (Warman 2003). While it called for greater investment in terms of physical labour, it contributed to the growth of the yield and to the economic value of arable land. This was a significant development for the vast number of small peasants that dominated the land ownership structure. In the fields, maize was often accompanied by two other crops: beans and pumpkins. Maize stalks also provided support to beans or pumpkin tendrils. It could also serve as a stubble crop, planted after other sorts of cereals had already been harvested. The fast-growing varieties of maize, imported from Italy, represented a typical example of this, as they matured in less than two months. Furthermore, various uses were discovered for dry maize stalks and maize cobs, and nothing was discarded. In the long term, productivity contributed to the popularity of maize. This 
was an essential element that explains why maize production expanded, replacing lentil or the older types of cereals like millet, spelt, or buckwheat.

Even language was affected by maize. The formation of what is allegedly an original Slovenian phrase represents a permanent trace. In the Slovenian language, the expression biti na koruzi ("to be on maize") or živeti na koruzi ("to live on maize") denotes an extramarital union. The phrase originated in the nineteenth century from the various practices of avoiding the control and restrictions of the profoundly traditional society of the time. This is where maize comes in: unmarried couples or lovers would secretly meet in the haven of maize fields or spend their nights in barns lying on the maize stover. The practice has since disappeared, but the idiom persists and attests to the fact that even completely economic historical phenomena can attain social connotations (FRAN 192).

The penetration of maize into the peasant economy and mentality therefore represents an extensive and complex historical issue. It is also an integral part of the long-term restructuring of agricultural activities and accompanying social processes, especially in the field of nutrition. This discussion presents a condensed overview of the significance of maize in Slovenia during the nineteenth and the first half of the twentieth century, until World War II. Two different economic contexts, separated by World War I, existed during this lengthy period. After World War I, the majority of the Slovenian territory was included in the Yugoslav state - an environment where the economic and social importance of maize was significantly higher. However, approximately one third of the Slovenian territory in the west was governed by Italy, where maize had, even traditionally, played a vital role. If Slovenia was a land of potatoes, Serbia, for example, was a land of maize. In the interwar period, Yugoslavia was one of the biggest maize producers and exporters. Slovenia and Serbia are examples of the development of regionally dissimilar economic structures with different roles of maize in farming and in agriculture in general. Therefore, this contribution also outlines the process of the introduction of maize in Serbia. Such a presentation is also useful because both of these traditions eventually merged into a single national economic space in the Yugoslav state and were influenced by the same economic and political forces.

\section{Between tradition and modernity: buckwheat or maize?}

The introduction already stated that maize had established itself completely in the first half of the nineteenth century. This was also reflected on the 
linguistic level, as the names for the plant and its crops changed during the introduction and general adaptation of maize. Initially and for a long time in the nineteenth century, maize was referred to as turšica/turščica, meaning "Turkish wheat", which had been derived directly from grano turco or türkischer Weizen. During the nineteenth century, the term koruza became established, which is a derivative of the Turkish term kokoroz/kukuruz (FRAN 193). The Franciscean Cadastre attests to the fact that maize was present, in larger or smaller quantities, throughout the territory. The two surveys carried out in the Slovenian Styria during the pre-March period confirmed the presence of maize in practically the entire territory of this region (Kuret 1985-1993). It was least frequent in the central part of Slovenia (Gospodarska 1970, 262), Carniola, and in Prekmurje, the easternmost region of the country.

The various dynamics were not only caused by different natural conditions, however. The swifter expansion of maize in certain parts can be ascribed to the influences from the lands where it had established itself more quickly. The western parts of Slovenia were in close contact with the Italian lands, where maize had already become very frequent, for example in the Padan Plain or Friuli, to list two of the most extreme cases. Good models encouraged the introduction of maize in the nearby fields. The Styrian part of Slovenia is also an extension of the Pannonian Plain, where maize production expanded rapidly, also in Croatia. The climate was favourable for maize as well, as a continental climate with warm and sufficiently moist summer months is characteristic for the majority of the Slovenian territory, which experts have been underlining since as early as the middle of the nineteenth century (Poskušnje 1850). Despite these factors, in Prekmurje, which is a part of the Pannonian Plain and enjoys favourable natural conditions, the introduction of maize was slower than in the other regions. This fact is normally explained with the marginal position of the Prekmurje region and its lag in the processes of economic and social modernization (Gospodarska 1970, 262-265). The different dynamics of maize adaptation also depended on the social context rather than solely on the economic one. The penetration of maize into Carniola supports this claim. For a long time, the central part of the Slovenian territory was slow to introduce maize, as the local population was strongly attached to buckwheat. The fact that buckwheat was a stubble crop contributed to this, but maize could fulfil the same function as well. The buckwheat tradition persisted for a long time in the nineteenth century: with its superior production po- 
tential, maize only gradually undermined the work organization and field structure adapted to buckwheat. This is also an opportunity to compare the various conceptions of the importance of individual crops and adaptation mechanisms, as well as to underline the components of the perception of either maize or buckwheat.

The introduction of maize was encouraged by professional organizations, agricultural societies, and the authorities. Despite the influence of these institutions, it took much convincing and practical demonstrations to persuade peasants to gradually dedicate a larger percentage of their fields to maize. The central part of the Slovenian territory, i.e. Carniola, represents an obvious example. The economic and social dilemmas and uncertainties that accompanied the introduction of maize are apparent from the contemporaneous press. Moreover, heated discussions took place in the newspapers between the advocates of either buckwheat or maize, as historians already noted decades ago (Gospodarska 1970, 262). The debate was relevant for the entire Slovenian territory, even though the articles focused on the conditions in Carniola. An article from 1846 is one such example: its very title - "Hvala ajde" or "Praise to Buckwheat" - indicated the clear standpoints of the text. Already in the introduction, the author employed the method of moral discrediting to support his arguments. First, he discredited "foreigners" who were not familiar with the local conditions yet reproached Carniolans for producing buckwheat, a less productive and more sensitive crop. This supposedly suggested that Carniolans prioritized tradition over "progress". The "learnedness" of certain natives represented another example of discrediting the "opponents" of buckwheat. This is an example of a preliminary discrediting of the expert approach aimed at increasing the overall productivity of agriculture and therefore calling for certain changes in the structure of crops and models of farming. It is an example of opposing the idea of "progress" and productivity as the driving force of the increasingly capitalist economy in agriculture. Such an expert approach supposedly neglected the experience of generations of peasants. Allegedly, experiments and models of good practices could not make up for their centuries of experience in farming. These reproaches were aimed at the advocates of maize in particular. The argument from the neighbouring Province of Carinthia - that the extensive introduction of maize had significantly improved the food situation and that famine was therefore no longer a permanent threat - did not carry much weight with the authors, whose concern was: "How shall we preserve the good name of our belov- 
ed buckwheat?". The author lists the reasons against the partial replacement of buckwheat with maize. Maize was supposedly demanding for the soil, which was purportedly less suitable in Carniola. The main argument, however, was the increased labour intensity of maize production. Should more maize be sown, peasants would not have the time to work with other crops. Buckwheat straw with added turnips and leftovers from flax oil production was supposedly more than sufficient for animal consumption. Buckwheat was seen as an indispensable component of human nutrition. "If Carniolan peasants do not produce buckwheat, they will not eat much bread. Almost all white wheat is spent for holidays, tributes, nobility, and other purposes - only buckwheat remains at home for cooking and baking bread." The shortage of buckwheat would supposedly result in a famine that maize would be unable to stop. Maize was also discredited because of the alleged poorer taste of maize bread and its unsuitability for cooking. Furthermore, maize flour dishes (žganci, a sort of spoonbread or mush, similar to polenta) purportedly required more lard (dressing) to come anywhere near the taste of buckwheat dishes. "It is true that maize mush with a lot of lard tastes good, but buckwheat mush tastes even better, does not require so much dressing, and is also much better with milk." As frost was supposedly rare in Carniola, there was no need to reduce the areas dedicated to buckwheat. The author attempted to offset the higher productivity of maize by referring to the buckwheat yield. He claimed that in the most favourable circumstances, the ratio of seeds to crops in the case of buckwheat was 1 to 16 , but he makes sure to refrain from mentioning the ratio for maize. Allegedly, buckwheat was indispensable because it ensured diversification and thus contributed to risk management in case of a potential shortage of other crops, like cereals or potatoes. The vital importance of buckwheat for honey production was brought up as well. In conclusion, the author also listed a few reasons related to the cultural landscape and nature that justified the extensive areas dedicated to buckwheat. Thus, he also described an idealized image of agricultural land and organization of agricultural work:

Buckwheat in flower bestows magnificent beauty on the landscape, as such fields appear to be sprinkled with flowers for weeks. They have a pleasant scent and provide the hardworking bees with so much honey and wax that beekeepers can earn quite a bit of money. Furthermore, buckwheat contributes and attests to the peasants' diligence. We often see them plough their fields and sow buck- 
wheat on one side, while they are still harvesting wheat or flax on the other side. It therefore happens that by the evening buckwheat has already been sown where wheat was still growing in the morning. A week later, such a field is already green again. In September, go visit the places and lands where buckwheat is not sown after other sorts of cereals, and you will see that the empty fields appear burnt. You will be eager to once again rest your eyes on fields covered in buckwheat and adorned with reddish-white flowers.

As a sort of a solemn promise, the author concludes the text by declaring: "In Carniola, we will therefore not give up buckwheat: it is ours and it will remain ours. Thank God for it!" (KRN 1846, Okra). Throughout the century, buckwheat persisted in the entire Slovenian territory, in particular as a stubble crop. In the last decades of the nineteenth century, a new, modernized frost-resistant variety of buckwheat was introduced. Its relevance was thus maintained for as long as the first decades of the twentieth century. Not including Istria, where it was not sown, the average percentage of buckwheat on arable land in 1875 amounted to approximately $16 \%$, and Styria was the province with an above-average share. By 1913, however, the percentage of buckwheat as a stubble crop had been reduced in all the provinces - not so much in Styria than in the Goriška region, where it declined by three quarters. Even in Carniola, where buckwheat was defended by passionate advocates, its share was reduced by a third. The reduction in the percentage of buckwheat was mostly caused by the introduction of various fodder plants (Gospodarska 1970, 266).

The opposite standpoints - that buckwheat needed to be partially replaced with maize - were published in 1854 . In that year, early frost considerably diminished the buckwheat harvest, as this crop was extremely sensitive to colder temperatures. Experts advised that larger quantities of maize be sown to avoid such a problem in the future. The process was not simple, however, because the opposing side claimed that buckwheat was irreplaceable in the concept of peasant economy for two reasons. One of its advantages was the fact that it was a stubble crop, which contributed to the economization of agricultural land. Another argument attested to the concept of an integrated peasant economy, as the buckwheat advocates kept underlining that this crop was indispensable for the widespread beekeeping. As bee pastures, buckwheat fields ensured the production of honey, which supplemented the peasants' income. The experts understood that changes could not be introduced instantaneously and that it was not sensible to put 
an end to the coexistence between buckwheat and beekeeping too quickly. However, they warned that because of the sensitivity of buckwheat to early frost, risks had to be neutralized or reduced, which could be done by gradually increasing the percentage of maize over that of buckwheat. Initially, the peasants could allocate a quarter of their buckwheat fields to maize. In this manner, they would familiarize themselves with the production potentials and usefulness of maize first-hand. However, the process should involve the introduction of those varieties of maize that were the most suitable for the local pedological and climate conditions. Its purpose had to be taken into account as well: maize as a stubble crop called for varieties that matured rapidly - the so-called činkvantin (from cinquantin; KRN 1855) and pignoletto (KRN 1880, Porenta). Elsewhere, maize was more suitable as the main crop, as it boasted a higher yield (KRN 1848). The general usefulness of maize was emphasized as well, as maize stalks were highly convenient as livestock feed. Even stripped maize cobs were useful. The suitable pedological conditions for the cultivation of maize and its resistance to frost were underlined as well (KRN 1850). Should the soil be too heavy, fertilization could ensure suitable conditions.

Peasants were being persuaded that with the appropriate sowing distance to ensure sunlight and heat, they could take advantage of maize fields by also planting beans and pumpkins. As maize needed to be hoed and dressed, the workload increased. Therefore, peasants were concerned that they would be unable to handle the additional work and would need to hire workers, which would be a too great burden for the scope and profitability of their economy. Twenty workers were required to dress a single hectare of maize in a single day. Calculations indicated that between twenty and twenty-five workers were needed to hoe the same amount of maize in a day. These facts caused considerable concern. The experts recognized that the peasants' doubts were well founded, but believed that the long-term productivity of maize in combination with additional crops and weeded fields more than made up for the increased physical effort. Later, in the 1880s, one of the arguments in favour of maize that was often mentioned was the possibility of using machinery for these purposes (KRN 1881), as the onetime expense to purchase the required agricultural machinery was, in the long term, offset by the increased productivity. For this reason, however, it was necessary to plant maize with the correct spacing between the rows and within rows. The peasants also kept underlining the reduced harvest of wheat, should maize expand as the main crop rather than merely as a stub- 
ble crop to replace buckwheat. The representatives of agricultural societies would respond to this concern by emphasizing the far greater productivity of maize and the necessity to increase the wheat yield in the remaining areas. The president of the Carniolan Agricultural Society thus concluded his appeal to the peasants - that they should consider the suitability of sowing buckwheat - with the following proclamation:

...that it is not prudent for those whose survival depends on their fields to rely solely on buckwheat. [...] Think about it yourselves, my friends! Do not take my words for granted, but consider it on your own and do not forget to take everything into account: seeds, labour and crop - both the grain and the straw harvest - as well as the value of every stalk. [...] Carniolans are hardworking people, it is only that they still keep relying on buckwheat too much!

Agricultural societies would supply peasants with subsidized seeds to facilitate the introduction of maize. Generally, subsidies as an economic encouragement represented an important element for the acceptance of maize. On their own, education and persuasion were not enough to change the traditional models and structure of the peasant economy. Agricultural societies encouraged the peasants to experiment and learn from their own experience, as well as from the knowledge of others. As the experts argued: "And if we do not listen to experience - proven experience - we only confirm the old saying that old habits die hard" (KRN 1854, Terpinc). In this regard, the author was certainly right. The preoccupation with tradition, existing models of farming, and the fear of change represented obstacles for the swifter introduction of maize. Changes, however, called for a leap into the unknown. New crops - and maize was definitely one such crop - called for new technologies, a different work organization, and partially also investments into new facilities or adaptation of the existing buildings to ensure the proper storage of maize. However, the path had been paved despite the reservations, and maize slowly gained importance. As the process was gradual, the peasants had enough time to adapt to the new production capabilities and technological demands that maize involved.

Simultaneously, maize was also becoming a part of the people's diet. Polenta and maize mush soon appeared on people's tables, and mixing maize flour with wheat flour was a familiar practice throughout the Slovenian territory. However, in Istria and in the Goriška region (near the border with Italy), maize was more common: it was mostly eaten in the 
form of polenta. The existing reports show that in the decades leading up to the turn of the nineteenth century, the maize harvest in Istria sufficed for four months. After that, peasants had to purchase additional maize. In the remaining part of the Slovenian territory, the crop allegedly sufficed for the annual needs of the population (Hrobat Virgolet 2018, 87). In Carinthia, maize mush was very popular, while Styria stood out in terms of mixing maize flour with other types of cereal flours. In the central part, cereal mushes still prevailed. Generally, the everyday diet of the rural population consisted mostly of mushes and potatoes. Maize dishes only supplemented or diversified everyday nutrition (Makarovič 1991, 156).

\section{The quiet advance of maize}

The statistical information about the percentage of maize confirms the nutritional patterns in the field of cultivation as well. These data reveal the long-term establishment of maize and its relation to other crops, which differed considerably from province to province. We can certainly claim that in the first half of the nineteenth century, the established relations between maize and other field crops persisted for a long time, until as late as World War I, as indicated in the following charts.

60

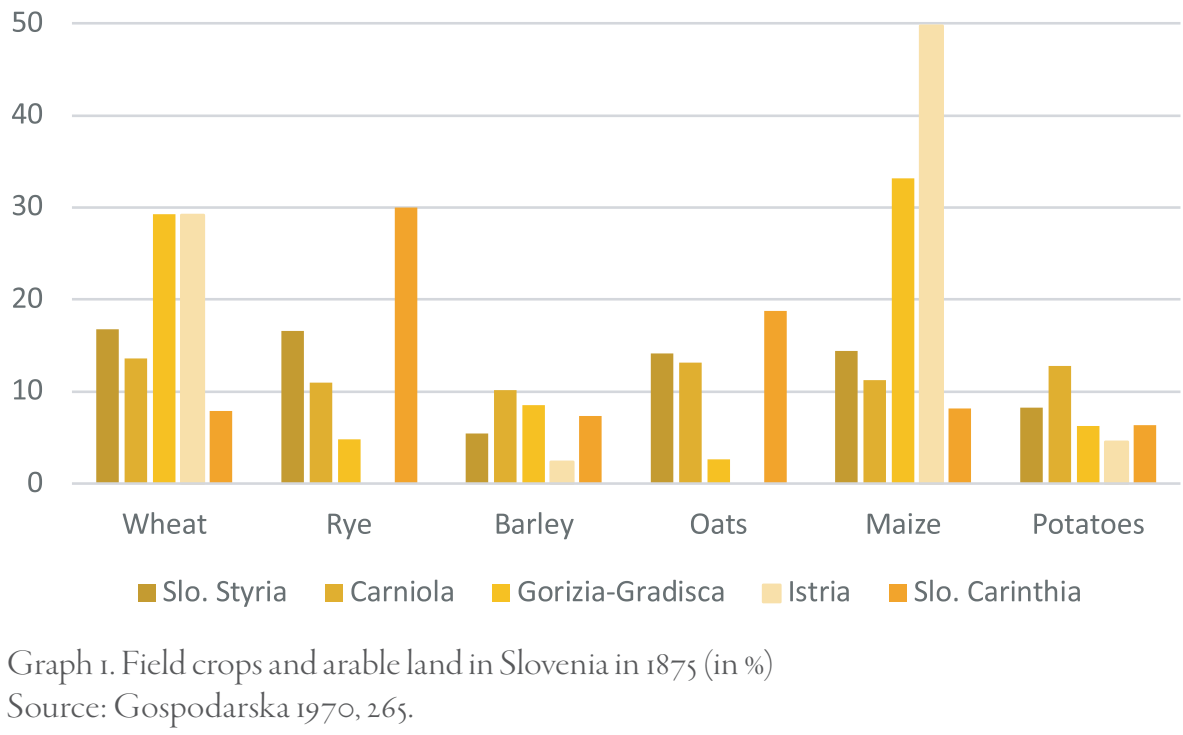




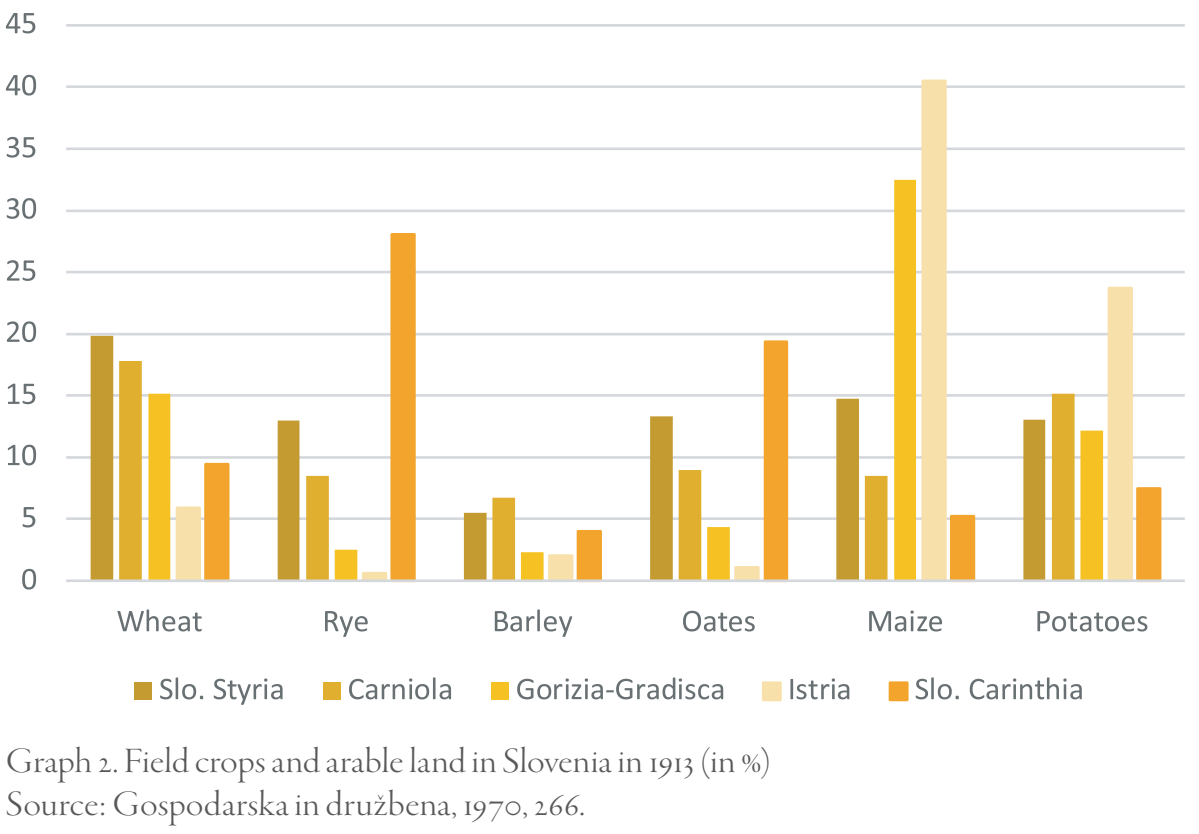

The role and share of maize varied notably between provinces. With the exception of western Slovenia (Goriška region and Istria), where maize was a staple crop whose share amounted to nearly one half, it was present in much more balanced percentages in the other provinces. In the east, the Slovenian Styria, where maize was sown in approximately $15 \%$ of the fields, exhibited a more diversified structure of crops in the long term. Meanwhile, in the central part of Slovenia (Carniola), maize did not establish itself to such a degree. In 1875, the percentage of arable land dedicated to it had amounted to approximately $12 \%$, but even that diminished to around $9 \%$ by World War I. This decline resulted from the expansion of potatoes. An interesting trend emerges when the absolute data regarding the surfaces of individual crops at the level of the Slovenian average is taken into consideration. The growth of absolute surfaces was not only registered in the case of potatoes, for example in Carniola, but also for wheat and maize. Areas dedicated to wheat, maize, and potatoes kept increasing throughout the nineteenth century. Until as late as the end of that century, maize had an advantage over potatoes. Other cereals, apart from wheat, were in decline. This was, in part, a confirmation of the process pattern: the more modest the yield of a crop, the smaller the percentage of surfaces dedicated to it in the long term. We state this with caution because the high percentage of buckwheat deviated from this pattern throughout the nineteenth century. 
Meanwhile, maize and potatoes with their high yield represented typical examples that confirmed the pattern. The expansion of surfaces dedicated to wheat was encouraged by its high price, however. Furthermore, the data reveal that the (poorer) population of (central) Slovenia increasingly prioritized potatoes, which assumed the role of staple food as the beginning of the twentieth century drew closer. Maize, on the other hand, was primarily used for animal consumption. The percentage of fields dedicated to potatoes tended to increase until World War I, which was a general Slovenian trend. Thus, it is not surprising that the majority of Slovenia soon attained the reputation of a land of potatoes in the self-image of its population. The western parts of Slovenia, where maize had an indisputable primacy, were too small to change the impression of Slovenia as a land of potatoes.

Regarding the yield per hectare, we can note an interesting tendency that maize yield was, in comparison with other cereals, the highest in the 188 os and 1890 s. Later, it was characteristic that the differences in the yields between cereals, with the exception of buckwheat, diminished, but maize still retained an obvious advantage. If we also take into account the possibility of combining maize with beans and pumpkins, the advantage of maize was indisputable. However, neither other cereals nor maize could match potatoes in terms of productivity. In the case of potatoes, the yield per hectare gradually increased throughout the nineteenth century. This fact further contributed to Slovenia's eventual reputation as a land of potatoes.

Interesting relations surface when we only observe the data for maize. It is completely obvious that during the decades leading up to World War $\mathrm{I}$, maize production kept changing in relation to weather conditions. After the beginning of the twentieth century, production and yield per hectare stabilized, indicating that in the context of the production technology at the time, further growth in productivity could not be expected. At the level of the entire Slovenian territory, the percentage of surfaces dedicated to maize remained more or less the same throughout the period under consideration. Only minimal deviations in individual years are notable, but they disappear when we calculate the areas as average five-year sequences.

Maize prices were directly dependent on production, demand, monetary value, and general economic circumstances. The long-term trends of maize prices in the Slovenian territory can be analysed based on the discussion by Vlado Valenčič (1977), who published the movements of cereal prices in Ljubljana spanning almost two centuries prior to World War I. 


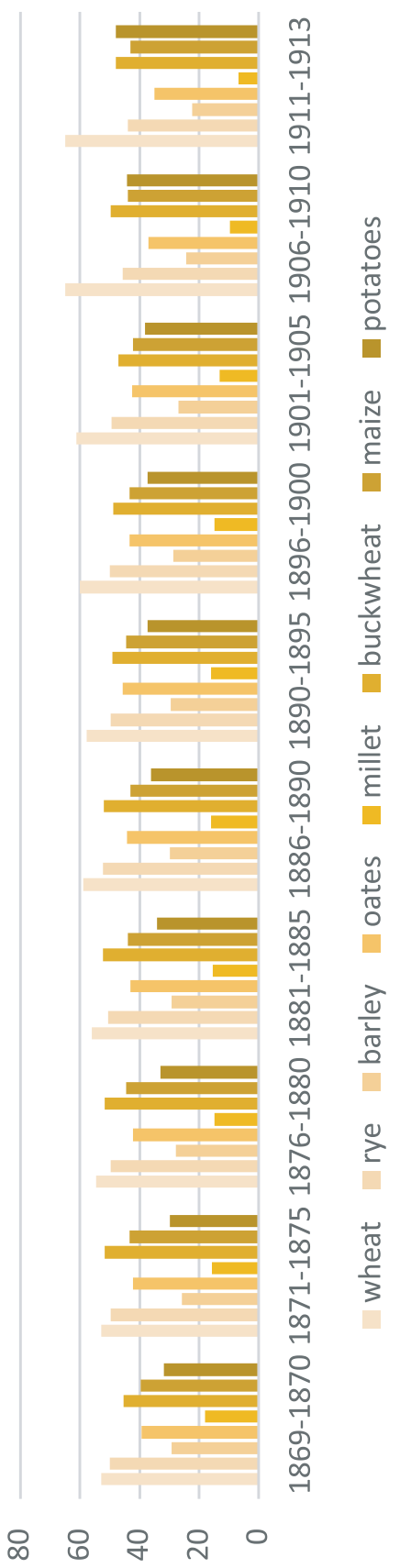

Graph 3. Surfaces dedicated to individual cereals and potatoes, I869-1913 (in I000 ha) Source: Maček 1993, I8-37 


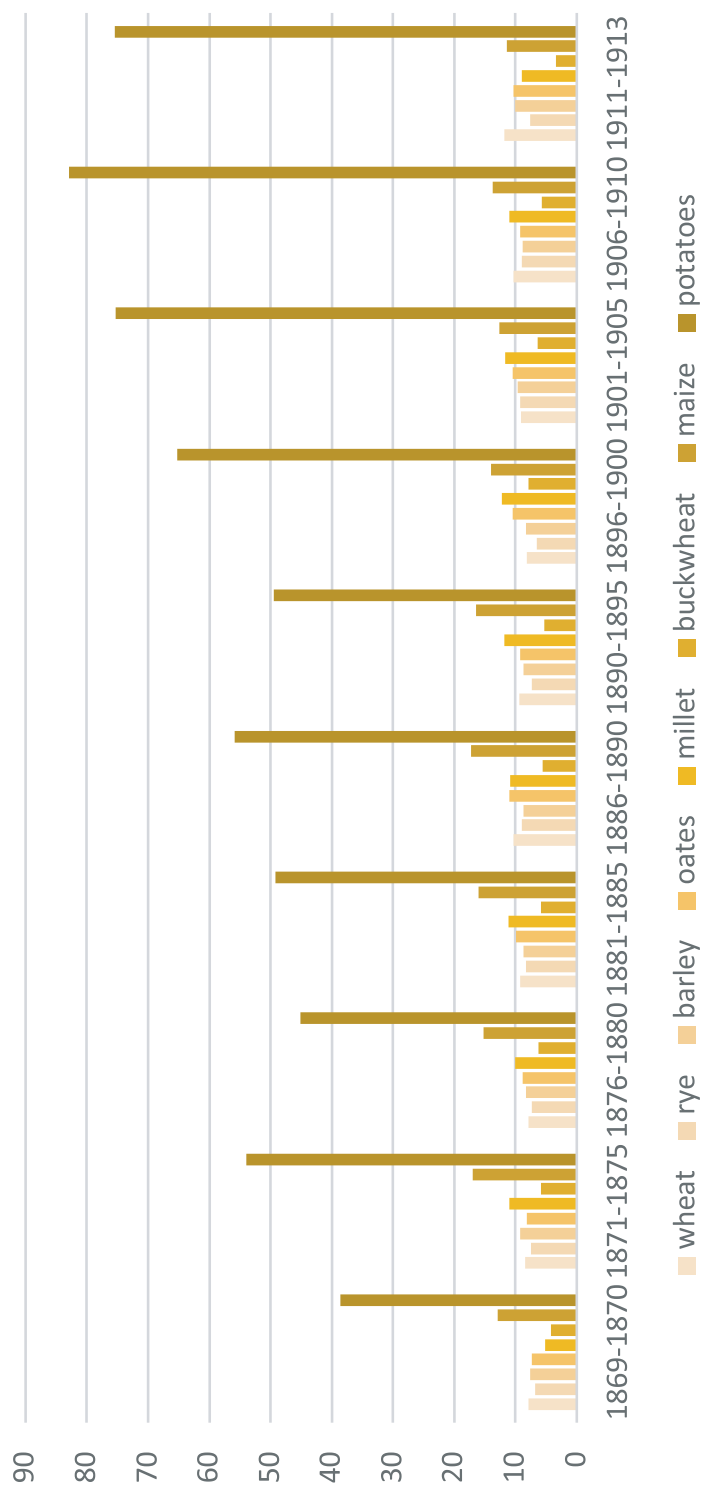

Graph 4. The yield per hectare of cereals and potatoes in Slovenia, I869-1913 (in q/ha) Source: Maček 1993, I8-37.

The data include maize, even though they are the least complete, particularly for the first half of the nineteenth century. In Ljubljana, the first trading in maize was registered in 1795. Since then and until as late as World War I, a sequence of data on maize prices exists, even if with short interrup- 


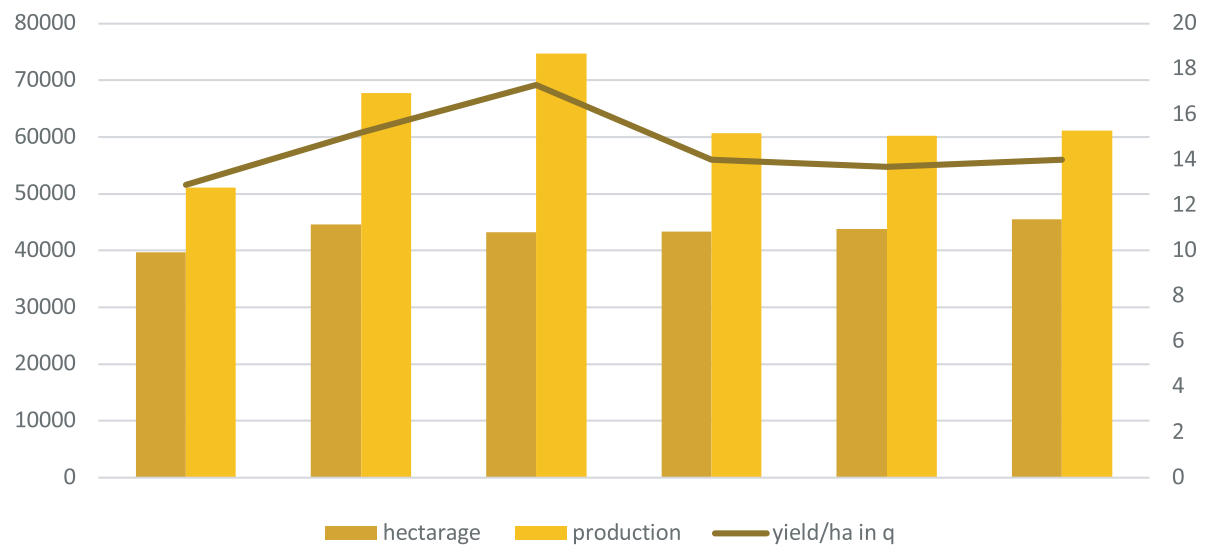

Graph 5. Surfaces, crops and yield of maize until World War I in Slovenia Source: Maček 1993,33-34.

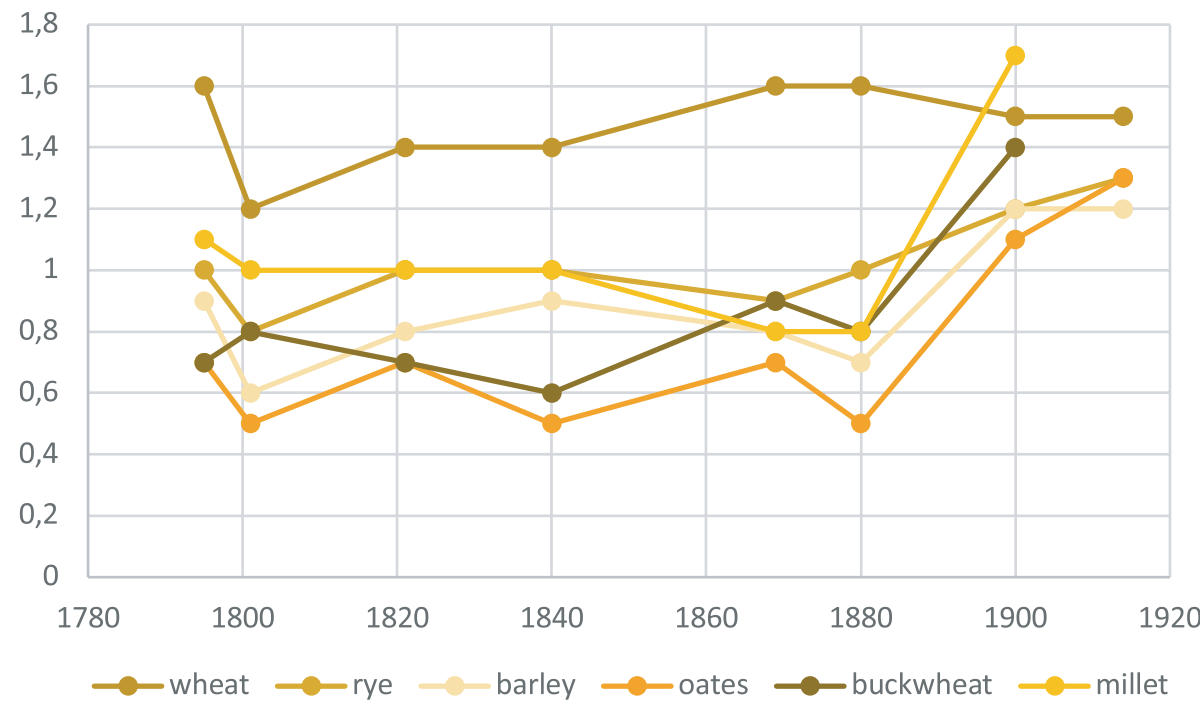

Graph 6. Relative price relations between maize and other cereals 1795-1914 (maize = I) Source: Valenčič 1977, 163-202.

tions. The analysis of price trends reveals that, except for a few oscillations, they remained stable in the long term. From the 1870s until World War I, the maize prices kept increasing slowly yet persistently.

For as long as a century, the long-term relative price relation in comparison with wheat as the most important cereal was preserved as well. The verification of the relative price for an equal amount of wheat or maize 
every twenty years reveals that the relation was quite stable. In the first half of the nineteenth century, the relative price of maize came the closest ever to that of wheat, amounting to approximately three quarters of the price of wheat. In the time up to World War I, the difference in prices increased and the relative price of maize settled at approximately two thirds of the wheat price. It is interesting that in the last decade of the eighteenth century, when the maize trade had only just begun in Ljubljana, the price relation was almost identical to that of shortly before World War I. These trends are also interesting in comparison with other cereals. With the exception of rye, whose relative price matched that of maize throughout the nineteenth century, other cereals (barley, oats, buckwheat, and millet) were relatively cheaper until the end of that century, when the relative price of maize diminished considerably in comparison with other cereals. This relative decrease in maize prices resulted from the increased supply, the slight expansion trend of the surfaces dedicated to maize, and the significantly higher yield per hectare.

\section{The prevalence of maize in Serbia}

The example of Serbia, which had a tradition entirely unlike Slovenia, will serve to illustrate a different role of maize. Naturally, maize was the fundamental driving force of field crop changes during the nineteenth century in Serbia, too. There, maize established itself much earlier than in Slovenia already at the beginning of the eighteenth century. In 1722, as much as $31 \%$ of fields were dedicated to maize (Stoianovich 1966, 1028). In the next century this process advanced considerably; in the agricultural structure of 1846 , the percentage of maize amounted to as much as $55 \%$. In the following two decades, it then settled at approximately $45 \%$ and persisted at this level until as late as World War I (Sundhaussen 1989, 246). As the charts demonstrate (Graph 2), only two Slovenian regions - the two western provinces near the border with Italy - boasted such a high percentage, namely $49.7 \%$ and $33.1 \%$ in 1875 , and only in the second half of the nineteenth century. However, they did not contribute much to the Slovenian average. The relations between the individual crops, explaining the long-term trends of the position of maize and its broader role in the Serbian peasant economy, are indicated in Graph 7.

In Serbia, the absolute numbers referring to the surfaces dedicated to maize kept increasing throughout the nineteenth century. This, however, was not due to the creation of new fields, but in fact reflected the process of 


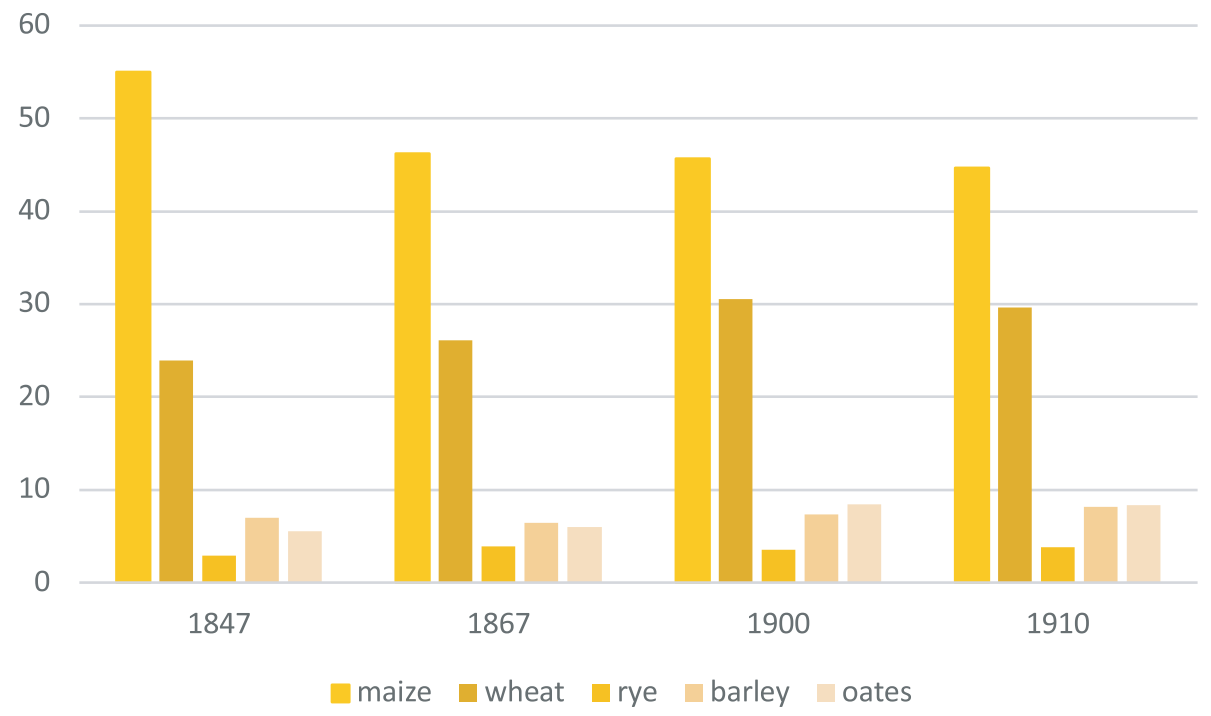

Graph 7. Field crops and arable land in Serbia (in \%)

Source: Sundhaussen 1989, 246.

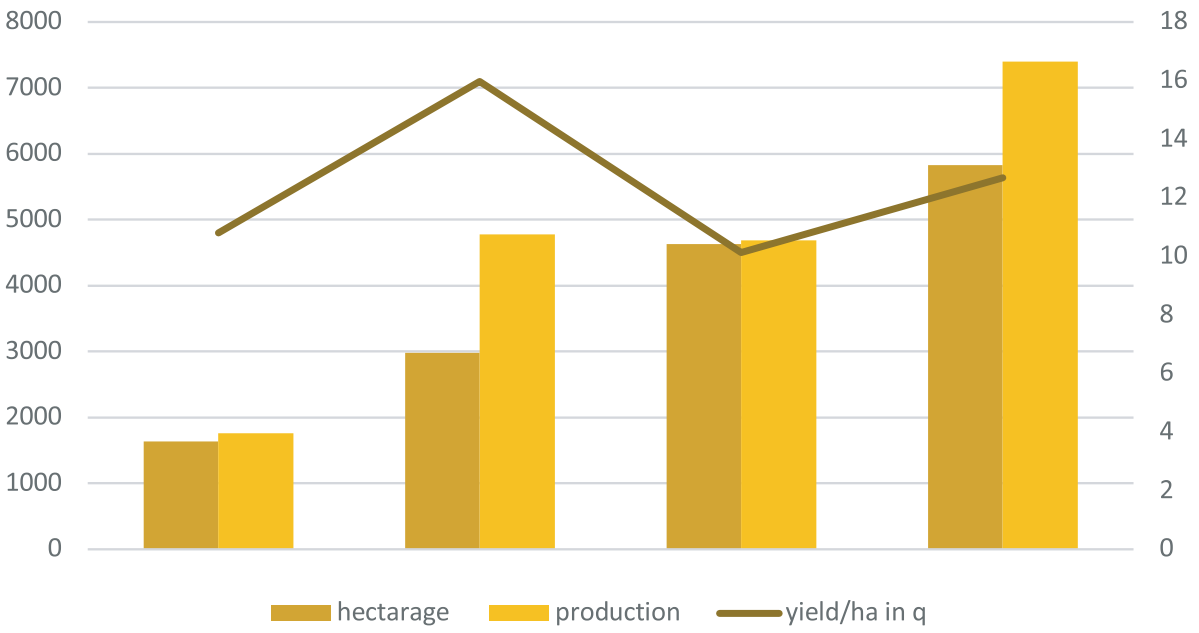

Graph 8. Maize crop in Serbia, 1867-1910

Source: Sundhaussen, 1989, 258.

the enlargement of the Serbian state, as it gradually expanded into the former territory of the Ottoman Empire. Therefore, the surfaces dedicated to maize kept increasing, as did maize production (Graph 8). Productivity or yield per hectare kept increasing most rapidly until the end of the 188os, 


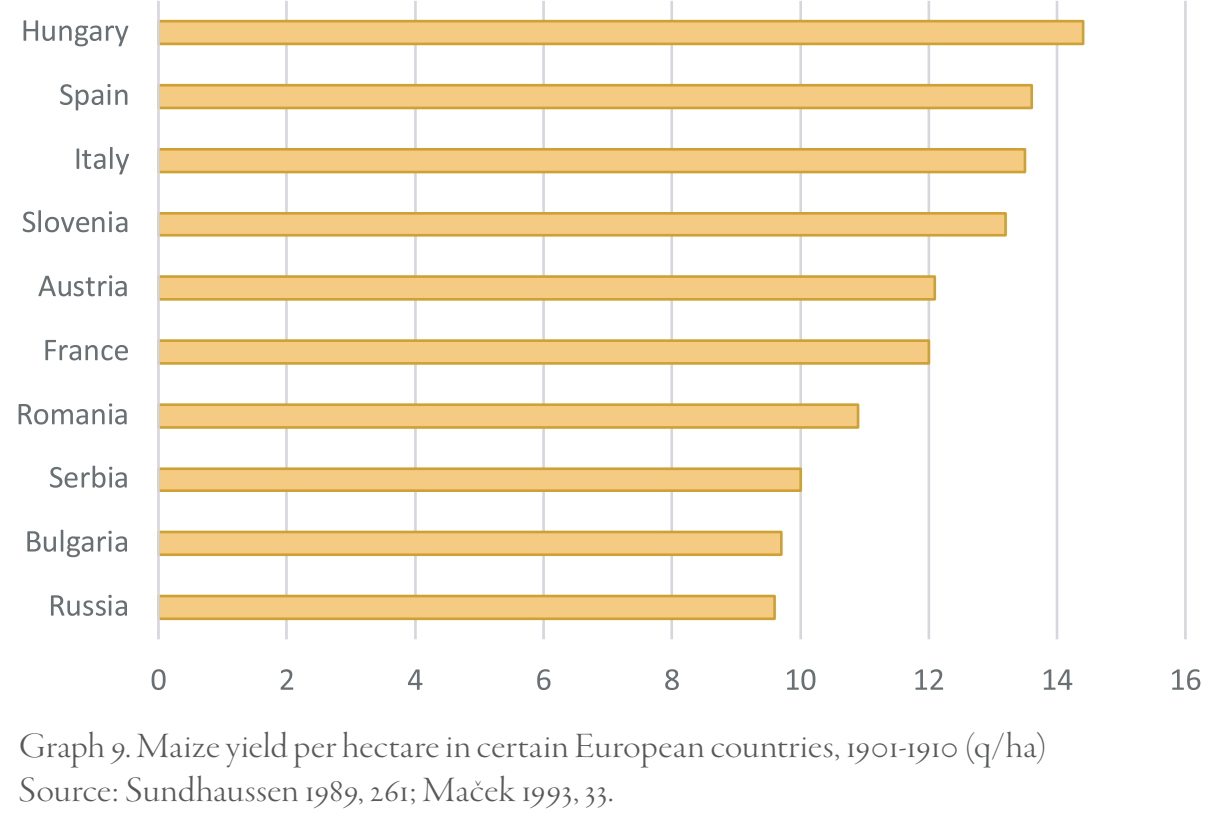

when they started to decline gradually until the end of the century. In the first decade of the twentieth century, however, they started increasing again. In the European context, Serbia was, in terms of productivity, among the countries with the lowest maize yield per hectare (Graph 9). The Pannonian Plain was the most productive area by far, followed by Spain and Italy. In terms of yield per hectare, the Slovenian areas were relatively high on the list. They were slightly different than the average in the Austrian half of the monarchy: thanks to Styria and the Prekmurje region - the two provinces located in the Pannonian Plain where the conditions were most favourable for the growth of maize - Slovenia boasted a higher yield per hectare. In the Pannonian Plain, the soil was sufficiently moist while summers were warm enough that maize could grow and mature properly.

The considerable share of maize in the agricultural structure resulted from the structure of the peasant economy that had established itself in Serbia. The vital importance of livestock farming was notable: live animals, especially pigs, were a dominant item, especially in exports. The Habsburg Monarchy was the most important market. Maize - in the form of young maize or maize grain - was irreplaceable as animal feed. It was widely used for cattle production and the dairy industry in particular. Pig farming was entirely maize-based. Even in horse nutrition, it would often replace oats 
and barley (Garić Petrović 2017, 109-110). At the same time, for a considerable part of the twentieth century, maize remained an important part of the everyday diet of the Serbian population (unlike the diet in the majority of Slovenia). Peasants would often sell wheat because of its higher price and purchase maize for food (Tomasevich 1955, 477). The majority of the population would eat maize bread daily, and they would also use maize flour to prepare other cooked and baked dishes. The records - occasionally even studies of the role of maize in the quality of meat and bacon, or analyses of its nutritional value for human and animal consumption - attest to the considerable role of maize in the peasant economy. Its influence on the quality of dairy products and on the taste and colour of eggs, when cattle and poultry were fed maize, was discussed as well (Nikolić 1931, 41). Such a role of maize also called for the use of different maize varieties, depending on its intended use. Varieties intended for maize flour differed from those meant for animal consumption. The selection of varieties and the creation of hybrids began very soon. As early as in 1872 , Đorđe Radić published a book that presented maize as a plant, the most sensible means of its production, and the initial results of crossing (hybridizing) different varieties (Radić 1872). Through hybridization, Radić wanted to create different varieties of maize that would best suit different purposes, as well as the Serbian pedological and climate conditions.

\section{The interwar period}

The end of World War I represented a significant turning point for Slovenia. Most of the Slovenian territory was incorporated into the Yugoslav state. In the new Yugoslav national economic space, agriculture was adversely affected by a change in relative prices (Bićanić 1973, 11-21). Consequently, the relative purchasing power of the peasant population decreased. Peasants represented the largest part of the population, also in Slovenia. Therefore, it is not surprising that agriculture found itself in a crisis already in the 1920s, even before the onset of the Great Depression (Lazarević 1994). With regard to maize, it was significant that Slovenia was integrated into an environment where the role of maize was much greater, which also determined the macro relations between the individual crops as well as the price movements on the internal market. With the establishment of the Yugoslav state, vast areas of the Pannonian Plain, previously included in the Hungarian half of the Habsburg Monarchy, became an integral part of the new state. Maize became the most important crop besides wheat, and Yugoslavia was one of 


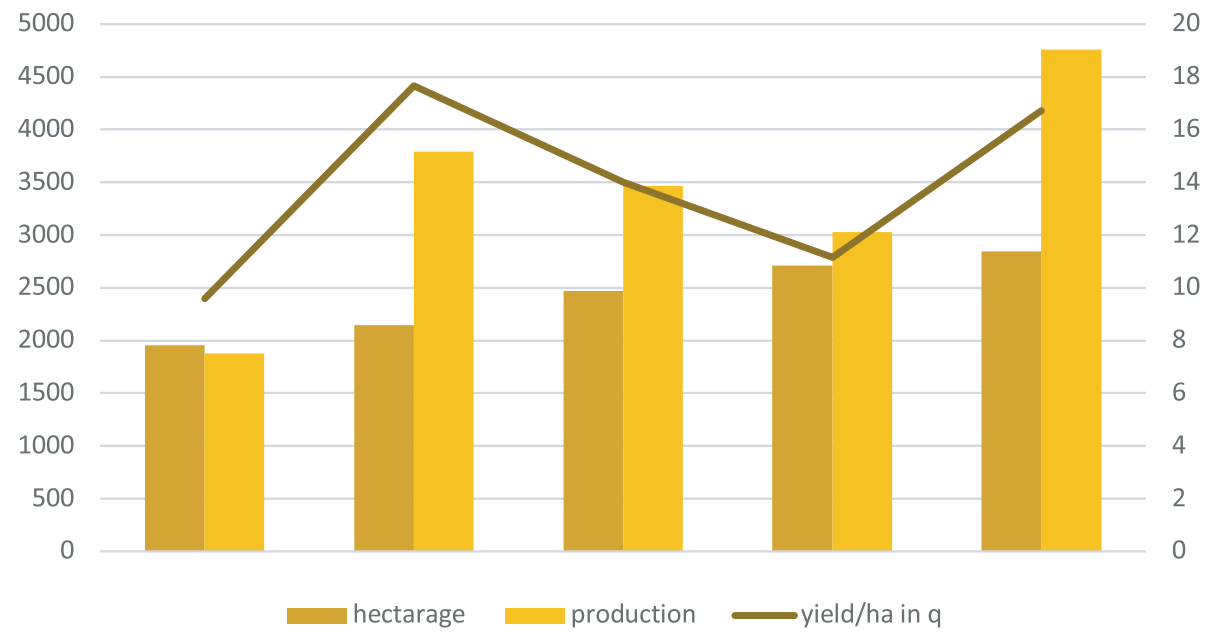

Graph Io. Maize production in Yugoslavia in the interwar period Source: Tomasevich 1955, 476.

the most important producers and exporters of maize in Europe. On average, maize exports represented $12.35 \%$ of all the exports due to the agrarian character of the Yugoslav state before World War II. Consequently, the share of exports in the national economy as a whole was also low (Nikolić 1931, 108-112). The export data should be further relativized. At the beginning of the 1930s, Yugoslavia exported only $8 \%$ of its total maize harvest, while the rest was required to satisfy the domestic demand (Nikolić 1931, 78). Maize was cultivated in all parts of the state, often also in the mountains to the maximum altitude of $1,200 \mathrm{~m}$, where special fast-growing varieties were cultivated. With its high yield and energy value, maize was indispensable in the diet of the people in the mountainous regions. In many parts of Yugoslavia, fertility rates were so high that only maize with its high yield was able to satisfy the demand for food. It is therefore not surprising that areas dedicated to maize cultivation kept expanding during the entire interwar period, while the productivity also increased (Graph 10). The greatest expansion of maize fields was recorded in the Yugoslav part of the Pannonian Plain - amounting to as much as $31 \%$ in the west, and up to $20 \%$ in the east. On average, since the 1920 s and until the onset of World War II, the Yugoslav maize fields expanded by $21 \%$. In the same period, productivity kept growing as well. The increases in yield slowed down somewhat only in the first half of the 1930s during the Great Depression, when exports were hampered and a few poor harvests were also recorded. The 


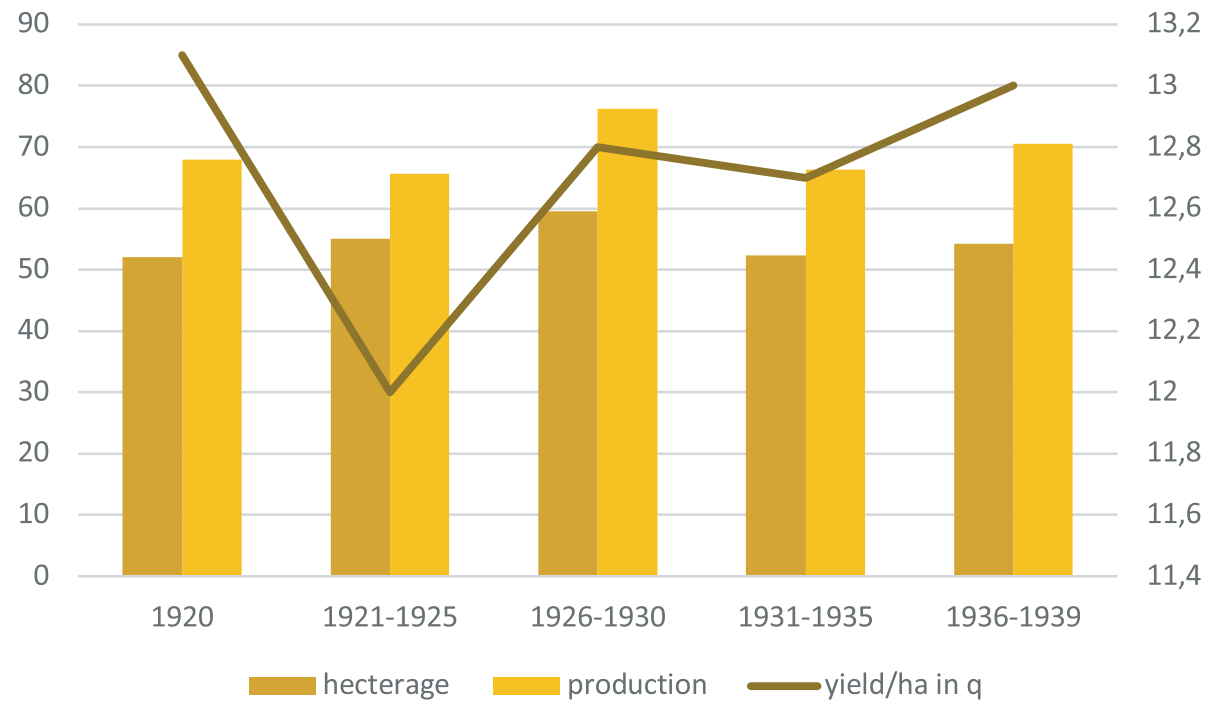

Graph Ir. Maize production in Slovenia in the interwar period Source: Maček 1993,33-34.

long-term growth in maize production could be explained with two factors. One of the factors was the international market, as Yugoslavia was one of the largest exporters of maize to the neighbouring countries, in the form of grain or live animals fed with maize. In the long-term, maize prices did not fluctuate as much as wheat prices, and the high level of demand remained stable. According to the studies of the period, the costs of maize were also relatively lower in comparison with those of wheat, although it required greater labour. At the same time, the relationship between the relative prices of maize and wheat tilted in favour of maize, as attested by the data from the areas in the Pannonian Plain that had the greatest influence over the formation of price relationships because most of the maize intended for the market was produced there (Vojvodina, Slavonija). In the 1930s, the ratio between the relative prices of wheat and maize amounted to 1.7:1, in line with the long-term values from the nineteenth century, as is also evident from Valenčičss calculations (Valenčič 1977, 163-202). On the other hand, the ratio between the yields of these two crops was 1:1.7 in favour of maize. In such circumstances, the increase of maize's share in the agricultural economy was evident (Tomasevich 1955, 482-488).

In the new macro-economic environment, the expansion of areas dedicated to maize also increased in Slovenia (Graph 11), although to a significantly lesser degree than in the other parts of the state. The areas ex- 
1921

\section{Graph 12. Maize yield in Yugoslavia}

Source: Tomasevich 1955, 476; Maček 1993,33-34.

panded slightly in the second half of the 1920s, only to swiftly return to the steady long-term level. The harvest volume recorded higher growth due to the proportionately higher yield. In the interwar period, maize yield remained at the same level as before World War II. In the new environment, where the relationship between prices was determined by the producers from the Pannonian Plain, the Slovenian yield was lower in comparison with the state average (Graph 12). However, the state average was high due to the most productive areas in the Pannonian Plain that had been among the most productive at the European level already before World War I. When compared with the other regions directly, Slovenian peasants were highly productive maize growers. The role of maize for livestock farming was still considerable, but it was significantly less important for human consumption.

\section{Ultimately, potatoes!}

During the interwar period, the "hundred-year competition" between maize and buckwheat in Slovenia ended (Graph 13). The surfaces dedicated to buckwheat had declined drastically already during World War I by approximately $40 \%$. After the war, the decrease continued in the first half of the 1920s, when the presence of buckwheat in the fields was min- 


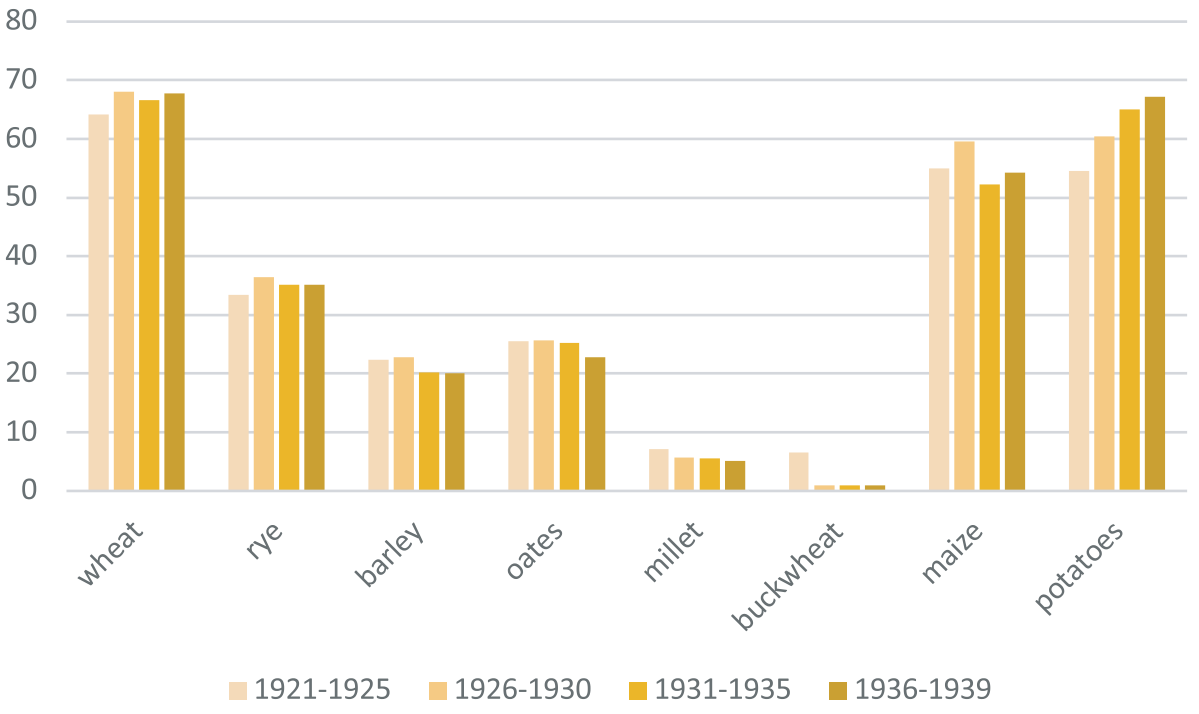

Graph I3. Field crops and arable land in Slovenia, 1921-1939 (in I000 ha)

Source: Maček 1993, I8-34.

80

70

60

50

40

30

20

10

0
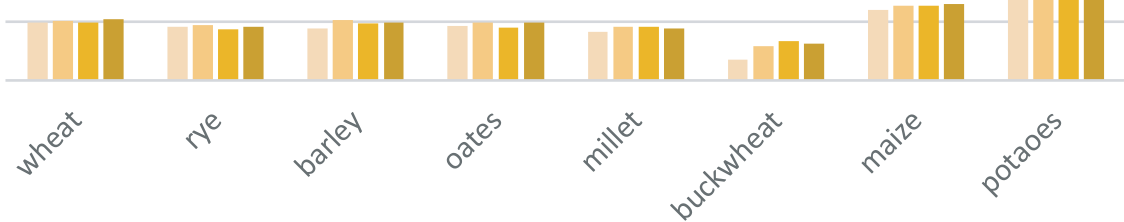

-1921-1925 -1926-1930 -1931-1935 -1936-1939

Graph I4. Yield per hectare of cereals and potatoes in Slovenia, 1921-1939 (in q/ha)

Source: Maček 1993, 18-34.

imal. In 1939, only $2 \%$ of the fields where buckwheat had grown in 1913 were still dedicated to it, which demonstrates how steep the decline was. The crop itself suffered the same fate, as it virtually disappeared from the 


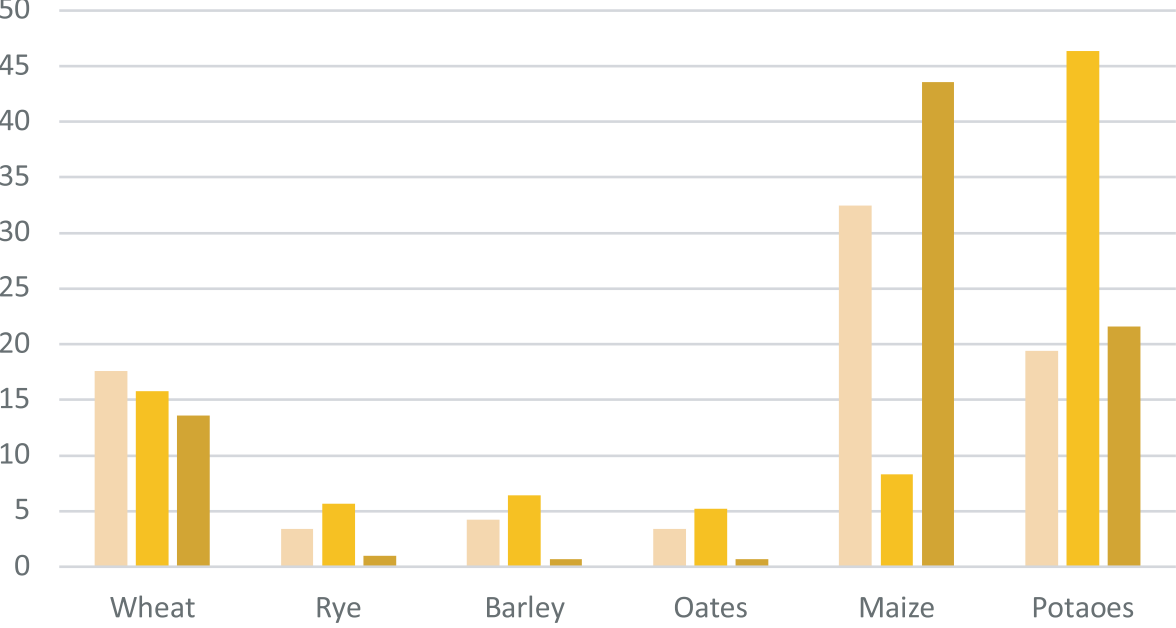

Gorizia-Gradisca $\square$ Notranjska $\square$ Istria

Graph 15. Field crops and arable land in western Slovenia in 1929 (in \%) Source: Gospodarska 1970, 269.

fields and the plates. On the other hand, the share of maize kept increasing. Buckwheat was therefore "collateral damage" of the altered macroeconomic environment in the new Yugoslav state. As the relative prices of agricultural products in comparison with industrial ones changed, peasants would more quickly abandon the poor-yielding crops, which buckwheat definitely was. Its yield per hectare was by far the lowest of all the cereals (Graph 14). Even millet had a better yield, and it nevertheless gradually disappeared from the fields. Growing buckwheat was completely irrational, as it called for too much time and labour. The peasants' "emotional attachment" to buckwheat, which had been so characteristic for the Slovenian circumstances a century earlier, succumbed to the efforts to ensure a rational economization of agricultural work. On the other hand, the value of wheat, maize, and potatoes was preserved or even increased in the new Yugoslav environment. It is understandable that fields where these crops were grown kept expanding during the two decades before World War II.

The western parts of Slovenia were exposed to similar processes. In the interwar period, these parts - approximately one third of today's Slovenian territory - were a part of the Italian state. There, maize had already traditionally been a dominant crop as well as a staple food of the people. In spite of the two economic contexts - the Yugoslav and the Italian one - the forc- 
es that were at work in both of these states were very similar. The increasing production of two kinds of cereal, wheat and maize, and of course that of potatoes is obvious (graphs 10 and 15). The prevalent role of maize was therefore by no means questionable after World War I. However, also in this part of Slovenia, the trend of the increasing importance of potatoes due to their superior yield per hectare was apparent.

In the entire territory populated by Slovenians, the nineteenth-century trend of focusing on crops with the highest yield per hectare therefore persisted. Furthermore, the yield per hectare of wheat, maize, and potatoes kept increasing steadily. In view of the presented data about the surfaces and yields, we can definitely conclude that the victory in the "hundred-year competition" between maize and buckwheat went to potatoes! Slovenia was indeed "a land of potatoes". The socioeconomic context of the time also contributed to this in a decisive way: as most of the population lived close to the existential minimum (Lazarević, 2015), sufficient nutrition was of primary concern.

\section{Maize in the everyday diet during the interwar period}

We have already stated that maize was an integral part of the nutrition of the Yugoslav population. However, as in all other cases, numerous differences existed within Yugoslavia. Yugoslavia was, after all, a land of contrasts. The roles of maize and potatoes were typical examples. In the interwar period, the share of potatoes among all crops in the territory of today's Republic of Slovenia amounted to a little more than a fifth. No other Yugoslav province had such a significant share of potatoes. Apart from Slovenia, potatoes were well represented only in certain parts of Croatia (Tomasevich 1955, 489). Serbia, where maize was the dominant crop and potatoes were introduced rather slowly, represented a contrast. It is therefore not surprising that Slovenia was deemed a land of potatoes, where this crop represented a staple food. In this sense, Croatia represented a transitional area on the way to Serbia, where maize had the role of staple food. In 1928, the Ministry of Agriculture published the results of a research on the nutrition of the population, which also attempted to evaluate the structure of nutrition in Yugoslavia. The results were published in the form of a state average, which obscured the profound regional differences in the structure of the everyday nutrition of the population (Table 1). 
Table I. Structure of the average annual consumption of cereals and potatoes per capita in Yugoslavia, 1928 (in kg)

\begin{tabular}{lc}
\hline Wheat & 97 \\
\hline Maize & 157 \\
\hline Barley & 30 \\
\hline Rye & 26 \\
\hline Oats & 2 \\
\hline Potatoes & 10 \\
\hline Total & 322 \\
\hline Daily average & 0.88 \\
\hline
\end{tabular}

\section{Source: Nikolić 1931, 35.}

In terms of averages, maize represented half of cereal consumption. In reality, however, this average did not exist. If the results were still representative for the majority of the state, they certainly failed to reflect the situation in Slovenia and the structure of food items there. In the case of Slovenia, maize should be replaced with potatoes. In the interwar period, approximately 400 to $500 \mathrm{~kg}$ of potatoes were produced annually per capita, in comparison with only 75 kilograms of maize even in the best of years (Maček 1993, 34-38). The majority of potatoes were used for human consumption, some as animal feed, and the rest for industrial purposes. There was no doubt, however, that the research demonstrated that the daily diet of most of the population in the majority of the state depended on maize.

The significant percentage of maize in nutrition posed numerous questions regarding the health effects of this relatively monotonous dietary pattern in certain parts of the state. Concerns were raised about the excessive dependence on maize and the associated risks. Italy - the Padan Plain provided an example of the phenomenon of pellagra, which the researchers were looking into as a consequence of a monotonous maize-based diet. On the basis of the information from the parts where maize was most common in nutrition, they concluded that the absence of pellagra could be ascribed to two factors. The first one was the extent of maize cultivation, and the other the consumption of beans. Peasants supposedly produced enough maize that they could discard whatever was spoiled (mouldy), and yet enough was left for human and animal consumption. Furthermore, the consumption of various types of beans that would normally be grown simultaneously with maize contributed to a more balanced diet in the long term (Nikolić 1931, 36-39). 


\section{Conclusion}

During the nineteenth century, maize established itself completely in Slovenian agriculture. In the last decades of the century, the promotion of maize cultivation was no longer required. Instead, the press, the expert literature, and organizations for the promotion of agriculture shifted their focus to education. Their aim was to improve the maize production technology to ensure an even better yield and broaden its use. The effects of maize adaptation were important in the long term. The Slovenian territory with its dissimilar regional dynamics of maize cultivation, its various economic applications or dietary uses did not represent a very special example. Quite the opposite: it was merely a local manifestation of the wider European processes that altered the structure of agriculture in the nineteenth century. In Slovenia too, maize thus represented an integral part of the restructuring and modernization of agriculture as well as of the peasant economy. In terms of its significance and impact, maize was similar to potatoes. A broader look reveals the process of a long-term rational economization of agricultural labour, called for by the modern capitalist economy. During this process, it was crucial to increase the yield or the profitability of agricultural labour to allow for the social modernization of the peasant population and encourage general economic development (Lazarević 1998). Until as late as World War II, peasants represented the most numerous stratum of the population. Due to the increased purchasing power of peasants, any increase in the profitability of agricultural labour had significant macroeconomic effects. Throughout the decades, the tendency that peasants should alter the patterns and shares of crops was strengthened in the organization of the agricultural economy. They would gradually adopt the most profitable crops with regard to the necessary investments of money and labour. Apart from potatoes, maize represented an impetus for changes in the agricultural structure and the foundations of the peasant economy. The considerable yield and multifaceted usefulness of maize contributed to its expansion. In the nineteenth-century central Slovenian space, it had to compete with buckwheat for its place in the fields. This, however, was only an apparent competition, as the actual rivalry took place between buckwheat and potatoes. Buckwheat - the dominant food item of peasants in the middle of the nineteenth century - was not replaced by maize. It was actually pushed out by potatoes. No cereal could compete with the economic value of potatoes - their extraordinary yield, nutritional value, and versatility. Maize and potatoes did not compete in the Slovenian territory. As imported and 
adapted crops, they supplemented each other in view of the pedological and weather conditions. They allowed the peasants, and the society in the broadest sense, to diversify and rationally exploit their economic potentials and avoid nutritional risks. In light of the increasing population and modest living standard, the latter was extremely important.

Bibliography

Published sources

KRN: Kmetijske in rokodelske novice

1846, 4 (41): Okra, 'Hvala ajde.' $14^{\text {th }}$ October 1846.

1848, 6 (10): 'Turšica.' $8^{\text {th }}$ March 1848.

1850, 8 (12): 'Poskušnje s turšico, ki se mala zgodnja turšica ali činkvantin imenuje.' $2 \mathrm{O}^{\text {th }}$ March 1850.

1854, 12 (76): Terpinc, 'Ali ajda - ali turšica?' $23^{\text {th }}$ September 1854.

1855, 13 (52): 'Laška koruza ali činkvantinka.' 30 $3 \mathrm{O}^{\text {th }}$ June 1855.

1880, 38 (13): Porenta, L. 'Pignoleto, zgodnja sorta koruze (sirka).' $31^{\text {th }}$ March 1880.

1881, 39 (34): 'Ali prav sadijo koruzo po Kranjskem?' $24^{\text {th }}$ August 1881.

\section{Literature}

Bićanić, R. 1973. Economic Policy in Socialist Yugoslavia. Cambridge: Cambridge University Press.

Britovšek, M. 1964. Razkrojfevdalne agrarne strukture na Kranjskem. Ljubljana: Slovenska Matica.

Erjavec, F. 1928. Kmetiško vprašanje v Sloveniji. Ljubljana: Jugoslovanska kmetska zveza.

Garič Petrovič, G. 2017. Zemljoradnja u Srbiji (1878-1912). Beograd: Istorijski institut.

Gospodarska in družbena zgodovina Slovencev, 1970. Zgodovina agrarnih panog, I, Agrarno gospodarstvo. Ljubljana: DZS.

Hrobat Virgolet, K. 2018. Kmečka "gospodarska prizadevnost" v slovenski etnologiji (19.-20. stoletje). In Preživetje in podjetnost, Integrirana kmečka ekonomija na Slovenskem od srednjega veka do danes, edited by A. Panjek and Ž. Lazarević, 75-90. Koper: Založba Univerze na Primorskem.

Kmetijstvo Dravske banovine, 1933. Ljubljana. 
Krajevni leksikon Dravske banovine, 1937. Ljubljana.

Kuret, N. 1985-1993. Slovensko Štajersko pred marčno revolucijo 1848: topografski podatki po odgovorih na vprašalnice nadvojvode Janeza (1811) in Georga Götha (1842). Ljubljana: SAZU.

Lazarević, Ž. 1994. Kmečki dolgovi na Slovenskem. Ljubljana: ZPS.

Lazarević, Ž. 1998. Slovensko kmetijstvo od zemljiške odveze do druge svetovne vojne. In Zbornik ob 100 letnici Kmetijskega inštituta, 13-30. Ljubljana: Kmetijski inštitut.

Lazarević, Ž. 2009. Plasti prostora in časa: iz gospodarske zgodovine Slovenije $v$ prvi polovici 2o. stoletja. Ljubljana: INZ.

Lazarević, Ž. 2015. Spremembe in zamišljanja. Gospodarsko-zgodovinske refleksije. Ljubljana: INZ.

Maček, J. 1993. Statistika rastlinske pridelave v Sloveniji v obdobju 1869-1939. Zbornik Biotehniške fakultete, Suplement 18. Ljubljana: Biotehniška fakulteta.

Maček, J. 1995. Uvajanje dosežkov agrarno-tehničnega prevrata $v$ slovensko kmetijstvo $v$ obdobju 1848-1941, Ljubljana: Biotehniška fakulteta, Suplement 21 - Agronomija.

Makarovič, G. 1991. Prehrana v 19. stoletju na Slovenskem. In O življenju in kulturi večinskega prebivalstva na Slovenskem v 19. stoletju. Slovenski etnograf 33/34: 127-205.

Nikolić, M. 1931. Jugoslavija i svetska proizvodnja i promet kukuruza. Beograd.

Panjek A., J. Larsson, and L. Mocarelli (eds.) 2017. Integrated Peasant Economy: Alps, Scandinavia and Beyond. Koper: University of Primorska Press.

Radić, Đ. 1872. Sve o kukuruzu Beograd.

Socialni problemi slovenske vasi, 1938. Ljubljana: Socialno ekonomski inštitut.

Spominski zbornik Slovenije, 1938. Ljubljana: Jubilej.

Stabej, J. 1977. Kruh ubogih: kulturnozgodovinski in jezikovni začrt zgodovine krompirja na Slovenskem. Ljubljana: SAZU.

Stiplovšek, M. 2006. Banski svet Dravske banovine. Ljubljana: ZIFF.

Stoianovich, T. 1966. Le maïs dans les Balkans. In Annales. Economies, sociétés, civilisations (21) 5: 1026-1040.

Sundhaussen, H. 1989. Historische Statistik Serbiens 1834-1914. München: Oldenburg Verlag.

Tomasevich, J. 1955. Peasant, Politics and Economic Change in Yugoslavia. Standford: Standford University Press. 
Valenčič, V. 1977. Žitna trgovina na Kranjskem in ljubljanske žitne cene od srede 17. stoletja do prve svetovne vojne. Ljubljana: SAZU.

Warman, A. 2003. Corn \& Capitalism: How Botanical Bastard Grew to Global Dominance. University of North Carolina Press.

Za izboljšanje življenjskih pogojev našega kmetijstva, 1939. Ljubljana: Kraljevska banska uprava.

\section{Web sources}

FRAN: Slovarji Inštituta za slovenski jezik Frana Ramovša ZRC SAZU

192: https://fran.si/192/janez-keber-frazeoloski-slovar-slovenskega-jezi$\mathrm{ka} / 4216108 /$ koruza

193: https://fran.si/193/marko-snoj-slovenski-etimoloski-slovar/42879o8/ koruza?View=1\&Query=turščica\&referencedHeadword=túrščica. 